\title{
Komendantka Oddziału Kuriersko-Wywiadowczego I Brygady Legionów. Aleksandra Szczerbińska i towarzyszki broni
}

\begin{abstract}
Streszczenie. Artykuł omawia powstanie i działalność Żeńskiego Oddziału Kuriersko-Wywiadowczego, na czele którego stała Aleksandra Szczerbińska. Po wycofaniu się z Kielc Oddziałów I Brygady 30 października 1914 r. Aleksandra Szczerbińska „Ola” objęła komendę nad oddziałem kobiecym z rąk Kazimierza Sawickiego. Dowodzony przez nią Żeński Oddział Wywiadowczy jako część Oddziału Wywiadowczego podlegał najpierw I Pułkowi Piechoty Legionów, a następnie I Brygadzie. W oddziale tym służyło 46 kobiet. Były to członkinie Związku i Drużyn Strzeleckich, które miały kilkuletnie wykształcenie wojskowe. W oddziale kuriersko-wywiadowczym służbę pełniły również kobiety należące do politycznych organizacji niepodległościowych. Postawa, odwaga, determinacja wywiadowczyń z Żeńskiego Oddziału Kuriersko-Wywiadowczego wielokrotnie znajdowała uznanie w opiniach Józefa Piłsudskiego.
\end{abstract}

Słowa kluczowe: historia kobiet, I wojna światowa, biografia.

$\mathrm{U}$ dział kobiet w pierwszej wojnie światowej nie został oszacowany, a walczyły one na wszystkich frontach. Wojenne relacje kobiet opisują przede wszystkim strach, straty moralne i materialne, krzywdy, których doznały, gwałty i upodlenie. Kobiety tradycyjnie włączyły się również w działalność dobroczynną i pielęgniarską. Praca z opaską Czerwonego Krzyża uważana była za wypełnienie misji kobiet w czasie wojny, które „dobrze wpisywało się w tradycyjne rozumienie kobiecości"!.

„Trudno wymienić wszystkie elementy składające się na całość doświadczenia wojennego kobiet. Są one inne niż męskie także ze względu na rolę matki, chroniącej życie i rodzinę, aby zabezpieczyć przyszłość, w czysto biologicznym

* Wydział Filozoficzno-Historyczny, Instytut Historii, Katedra Historii Polski XIX wieku, e-mail: prepudrech@o2.pl

${ }^{1}$ A. Chwalb a, Samobójstwo Europy. Wielka wojna 1914-1918, Kraków 2014, s. 433. 
znaczeniu"2 - zauważyły autorki wstępu do pracy poświęconej wojennemu doświadczeniu kobiet. To Aleksandry Szczerbińskiej i jej towarzyszek broni jest odmienne od męskiego, ale jednocześnie w wielu aspektach bardzo zbliżone. Wybrały one żołnierski los, stanęły do walki i działań wywiadowczych na froncie.

Aleksandra Szczerbińska i współpracujące z nią w czasie pierwszej wojny światowej kobiety charakteryzuje szczególne podejście do wojny. Obcy był im strach przed konfliktem zbrojnym, uważały, za Komendantem Piłsudskim, że tylko dzięki wojnie Polska odzyskać może niepodległość. Osobiste doświadczenie wojny często bywało dla nich bolesne, ale udział w niej stanowił ich świadomy wybór.

W Przedmowie do pamiętnika Zofii Zawiszanki Aleksandra Szczerbińska pisała o tym, że kobiety w wojnach i powstaniach walczyć musiały nie tylko z wrogiem, lecz także uprzedzeniami opinii publicznej. Taki los nie ominął również uczestniczek pierwszej wojny światowej, w tym wywiadowczyń I Brygady: „Wielu małodusznych ludzi nie umiało ich zrozumieć i dużo $\mathrm{z}$ tego powodu miały ciężkich przejść, lecz się ich nie ulękły, dały pracę nową, bezinteresowną, nieznaną w historii wojen, dały wywiad oparty na znajomości sztuki wojennej [...] - wywiad sumienny, ścisły - taki, który mógł być podstawą do operacji taktycznych i strategicznych"3.

Udział kobiet w wojnie oznaczał przede wszystkim prace w służbach pomocniczych i sanitarnych, która została doceniona przez dowództwo Legionów. Kobiety po macierzyńsku troszczyły się o potrzeby Legionistów. Była to misja doniosła, ponieważ w szeregach Legionów znalazło się wielu bardzo młodych mężczyzn, którzy nadal potrzebowali matczynej opieki ${ }^{4}$.

Kobiety wzięły również udział w walkach w polu, w męskich mundurach. Bezpośredni udział kobiet w boju nie był w pełni akceptowany przez dowództwo Legionów. Maria Wołoszyńska vel Alfred Wołoszyński, Maria Błaszczykówna vel Tadeusz Zalewski, Wanda Gertz vel Kazimierz Żuchowicz, Zofia Plewińska vel Leszek Pomianowski, Ludwika Daszkiewiczowa vel Stanisław Kepisz, po pokonaniu wielu przeszkód, znalazły się w oddziałach i walczyły razem z mężczyznami. Oddziały opuściły po ostatecznym zakazie udziału kobiet w walce. Piłsudski wydał rozkaz nakazujący „odesłanie z powrotem do Krakowa wszystkich niewiast ciągnących z armią," 10 września 1914 r. Udział kobiet w walkach

M. Grzywacz, M. Okupnik, Wstep, [w:] Kobiety i/a doświadczenie wojny 1914-1945 i później, red. M. Grzywacz, M. Okupnik, Poznań 2015, s. 11.

${ }^{3}$ A. Piłsudska, Przedmowa, [w:] Z. Z aw is zan ka, Przez fronty. Pamiętnik wywiadowczyni 1 pułku piechoty Legionów z 1914 roku. Na podstawie notatek spisanych w lutym-marcu 1915 r., Warszawa 1928, s. XI.

${ }^{4}$ A. S tru g, Wiekopomny dzień 6 sierpnia 1914, Warszawa 1926, s. 27.

${ }^{5}$ A. Ci śślikowa, Udział Polek w pierwszej wojnie światowej, [w:] Kobiety w konspiracji pierwszej i drugiej wojny światowej. Materiały z sesji popularnonaukowej w Krakowie w dniu 18 maja 2005 roku, red. K. Minczykowska, J. Sziling, Toruń 2006, s. 17. 
stanowił więc krótki epizod wojenny, ale jak ważne było dla nich przywdzianie legionowego munduru, świadczą zdjęcia, które zostały zrobione w męskich mundurach i krótko ostrzyżonymi włosami. Po opuszczeniu oddziałów część z nich znalazła się w Oddziale Kuriersko-Wywiadowczym I Brygady Legionów.

Wojna nie zaskoczyła kobiet. Przygotowywały się one do działań zbrojnych oraz pracy w służbach pomocniczych co najmniej od 1909 r. Wówczas do Lwowa zostały przeniesione władze naczelne Polskiego Związku Wojskowego (dalej: PZW) z Mieczysławem Neugebauerem na czele. Polski Związek Wojskowy zastąpiony został organizacją o nazwie „Armia Polska”, której działania zorganizowano w czterech okręgach wojskowych: I lwowskim, II krakowskim, III warszawskim, IV wiedeńskim. Nastąpiła również zmiana form organizacyjnych. Rozpoczęto rozbudowę oddziałów, do których wstępować miała młodzież szkół średnich. Dnia 31 lipca 1911 r. zalegalizowano Polskie Drużyny Strzeleckie (dalej: PDS), które stały się jawną organizacją paramilitarną ${ }^{6}$. Początki wojskowego przygotowania kobiet miały charakter niezorganizowany i doraźny. Pierwszy żeński akademicki kurs Polskiego Związku Wojskowego odbył się w 1910 r. pod kierunkiem M. Neugebauera we Lwowie. Miał on charakter przygotowawczy, wzięło w nim udział 11 kobiet, m.in. Maria Barthel de Weydenthal, Leokadia Błońska, Zofia Dobijanka, Jadwiga Kadyjówna, Maria Konopacka, Elżbieta Kwiatkowska, Zofia Kopystyńska, Maria Wyczańska i Wanda Martynowiczówna. Utworzyły one Żeński Oddział lwowskiego PZW pod komendą Janiny Zakrzewskiej. Działania te zapoczątkowały rozwój żeńskich oddziałów strzeleckich.

Podczas kursu uczono się m.in. zasad musztry, terenoznawstwa, intendentury, podstaw służby wywiadowczej oraz sanitarnej, a także czytano regulaminy wojskowe, specjalistyczną literaturę i instruktażowe broszury, w coraz większej ilości wydawane przez organizacje strzeleckie. Wkrótce absolwentki pierwszych kursów same objęły funkcje instruktorek napływających do organizacji nowych ochotniczek ${ }^{7}$. W 1911 r. oddziały żeńskie dopuszczono do udziału w ćwiczeniach terenowych dla trzech lwowskich kompanii PDS. W tym samym czasie działał też już oddział żeński w Krakowie (jego organizatorką była Zofia Zawiszanka), a przy komendzie tajnej „Armii Polskiej” powołano Komisję Oddziałów Pomocniczych, która miała objąć ogólny nadzór nad szkoleniem zgłaszających się do organizacji kandydatek. W 1912 r. zakonspirowane „Koło Żeńskie PDS” powstało również w Warszawie, a na jego czele stanęła Maria Kwiatkowska. Łącznie w przededniu wybuchu wojny w działających w ramach PDS Oddziałach Żeńskich (oficjalnie używano tej nazwy od stycznia 1913 r.) znajdowało się

${ }^{6}$ J. D u frat, Kobiety w kręgu lewicy niepodległościowej. Od Ligi Kobiet Pogotowia Wojennego do Ochotniczej Legii Kobiet (1908-1918/1919), Toruń 2001, s. 58-59; M. Wr zo s e k, Polski czyn zbrojny podczas pierwszej wojny światowej, Warszawa 1990, s. 31-34.

${ }^{7}$ H. B a g iń s k i, Utworzenie organizacji skautowej w Sokole, [w:] Zarzewie 1909-1920. Wspomnienia i materiaty, red. A. Garlicka, Warszawa 1973, s. 418. 
blisko 200 kobiet, uczących się na kursach różnego szczebla (rekruckich oraz podoficerskich) i specjalności (sanitarnych, intendenckich, wywiadowczych) ${ }^{8}$. Na czele Wydziału Żeńskiego, kierującego ich pracą, stanęła Zofia Dobijanka9.

Do pracy w Związku Strzeleckim (dalej: ZS) kobiety dopuszczone zostały znacznie później, bo formalnie dopiero w listopadzie $1912 \mathrm{r}$. Nie decydował o tym jednak brak chętnych kandydatek, lecz stanowczy opór kierownictwa Związku.

Oddziały Żeńskie PDS czerpały kadry ze środowisk studenckich związanych z ruchem zarzewiackim. Znacznie trudniej podjęcie decyzji o przystąpieniu do organizacji podobnych oddziałów przebiegało w łonie Związku Strzeleckiego. Wywodzący się z Polskiej Partii Socjalistycznej (dalej: PPS) dowódcy ruchu strzeleckiego sprzeciwiali się zorganizowaniu oddziałów żeńskich. Udział kobiet w rewolucji 1905 r. i działalność w partii nie były wystarczającymi argumentami do zaangażowania kobiet $\mathrm{w}$ prace wojskowe.

Józef Piłsudski długo zwlekał z podjęciem decyzji o zorganizowanym włączeniu kobiet w działalność Związku, obawiał się bowiem śmieszności. Uważał, że utworzenie oddziałów kobiecych mogło jedynie zaszkodzić niepopularnej organizacji, za którą uważał Związek Strzelecki. Szczerbińska oraz Maria Turzyma wywierały naciski na Piłsudskiego, aby zezwolił na organizowanie się kobiet w ramach Związku.

Jesienią 1912 r. za zgodą Piłsudskiego przystąpiono do organizacji kobiecych oddziałów strzeleckich. W listopadzie Rada Oficerska ZS podjęła decyzję o tworzeniu żeńskich sekcji strzeleckich. Było to podyktowane rozwojem Oddziałów Żeńskich PDS oraz tym, że członkinie lwowskiego „Promienia”: Janina Benedekówna, Maria Rychterówna i Janina Tołłoczkówna podjęły szkolenia wojskowe na kursach przy Żeńskim Oddziale PDS pod kierunkiem Jadwigi Kadyjówny. Ponadto wiosną 1912 r. w Krakowie kilka działaczek „Promienia”: Halina i Maria Sawickie, Zofia Strzałkowska, Czesława Grünbaumówna i Maria Dylążanka utworzyły nieformalny oddział. W działalności i organizacji szkoleń wspierał je Julian Stachiewicz ${ }^{10}$.

Historia kobiecego Oddziału Kuriersko-Wywiadowczego jest ściśle związana z formującym się wywiadem I Brygady Legionów. Józef Piłsudski przywiązywał wielką wagę do organizacji wywiadu, którego działania miały się stać kartą przetargową w rokowaniach z Austriakami. Organizację wywiadu chciał powierzyć Marii Łopuskiej i Józefie Rodziewiczównie, które były doświadczonymi działaczkami PPS. Rozmowy z obiema prowadziła Aleksandra Szczerbińska, która otrzymała od nich odpowiedź odmowną, nie chciały one bowiem zostać "austriackimi szpiclami”"

${ }^{8}$ A. Marcinki ew i z-Gołaś, Ochotnicza Legia Kobiet (1918-1922), Warszawa 2006, s. 25.

9 Zarzewie - niepodległościowych ruch młodzieżowy w latach 1909-1920, [w:] Zarzewie 1909-1920. Wspomnienia i materiaty, red. A. Garlicka, Warszawa 1973, s. 72.

10 J. Dufrat, op. cit., s. 71.

11 A. Piłsudska, Udział kobiet w walkach o niepodległość, „Niepodległość” [Londyn] 1955, t. V, s. 183; J. Du frat, op. cit., s. 119. 
Na przełomie lipca i sierpnia 1914 r. zostało utworzone przez J. Piłsudskiego Biuro Wywiadowcze przy Komendzie Głównej. Na czele tej jednostki organizacyjnej stanął Walery Sławek „Gustaw”, który był odpowiedzialny za wszystkie działania wywiadowcze. Na rozkaz szefa sztabu Kazimierza Sosnkowskiego wszelkie wiadomości dotyczące działań wojsk rosyjskich miały być przekazywane na ręce W. Sławka. Chodziło przede wszystkim o informacje na temat rozlokowania, stanu liczebnego, koncentracji wojsk rosyjskich ${ }^{12}$. Pierwsze grupy wywiadowcze skierowano do Zagłębia.

Wśród pierwszych wywiadowców znalazła się Zofia Zawiszanka, która przeprowadzała wywiady nadgraniczne w kierunku Słomnik i Miechowa, wykonując polecenie J. Piłsudskiego. Dnia 2 sierpnia wyruszyła na zwiad, podczas którego ustaliła miejsce pobytu rosyjskiej brygady straży granicznej: „Nie pamiętam już, czy sama zgłosiłam się do niego z pomysłem zorganizowania wywiadów nadgranicznych - czy też on mi z góry dał to polecenie. Na razie miałam zbadać stan rzeczy w Słomnikach i złożyć o tym raport [...] cieszyłam się w duchu z zamiany roboty organizacyjnej na wywiady i agitację w terenie, prawie że już wojennym, na szerszą zakrojone skalę i nęcące niebezpieczeństwem"13.

Już 3 sierpnia Z. Zawiszanka była z meldunkiem w Krakowie u J. Piłsudskiego i K. Sosnkowskiego. Wówczas dowiedziała się, że będzie oddawać raporty na ręce W. Sławka, do Biura Wywiadowczego: „Ucieszyłam się, że będę pracować pod kierunkiem znanego mi już i sympatycznego człowieka. Kazano mi również postarać się o przerwanie linii telegraficznej między Słomnikami a Miechowem"14. W Biurze Wywiadowczym otrzymała również ulotki i odezwy, które miała rozpowszechniać w celu prowadzenia akcji informacyjnej ${ }^{15}$. Pierwsza wywiadowczyni I Brygady towarzyszyła oddziałom legionowym wkraczającym w nocy z 5 na 6 sierpnia 1914 r. na teren Królestwa Polskiego. W nocy Z. Zawiszanka oraz towarzyszący jej Janusz Sęp-Dłużniakiewicz pojechali do Jędrzejowa, aby sprawdzić, czy Rosjanie nie przygotowali zasadzki.

Dnia 5 sierpnia 1914 r. nastąpiły zmiany organizacyjne w Biurze Wywiadu. Walery Sławek przekazał dowództwo nad oddziałem wywiadowczym Rajmundowi Jaworowskiemu „Świętopełkowi” („Światopełkowi”). Nowy dowódca stanął na czele oddziału wywiadowczego, w skład którego wchodziła komenda i trzy pododdziały: beków (byłych bojowców PPS-Frakcji Rewolucyjnej), skautów i żeński. Na czele oddziału kobiecego stanął początkowo Kazimierz Sawicki „Zawisza”. Formowanie żeńskiego oddziału Kuriersko-Wywiadowczego trwało od sierpnia do września 1914 r. Początkowo wchodził w skład oddziału

12 J. Gaul, Na tajnym froncie. Działalność wywiadowczo informacyjna obozu niepodległościowego w latach 1914-1918, Warszawa 2001, s. 100.

13 Z. Zawiszanka,op. cit., s. 3-4; J. Gau 1, op. cit., s. 101.

14 Z. Zawiszanka,op. cit., s. 12.

15 J. Gau 1, op. cit., s. 103. 
o nazwie Oddział Wywiadowczy Wojsk Polskich, następnie od 27 sierpnia 1914 r. - Oddziału Wywiadowczego I Pułku Piechoty Legionów, a od 19 grudnia 1914 r. - I Brygady Legionów ${ }^{16}$.

Dnia 10 września 1914 r. nastąpił podział oddziału Kuriersko-Wywiadowczego na dwie grupy. Spowodowane to zostało załamaniem ofensywy Państw Centralnych i odwrotem z Kielc. Oddział żeński znalazł się wówczas pod komendą Adama Skwarczyńskiego „Starego” i skierowany został do Olkusza. Skwarczyński był zastępcą R. Jaworowskiego. Oddział kwaterował w Olkuszu od 11 do 14 września, następnie został przeniesiony do Krakowa. W mieszkaniu Ignacego Daszyńskiego w Krakowie znajdowało się biuro oddziału, który przebywał w mieście od 15 września do 5 października 1914 r. „Odlatuje już ostatni gołąb pocztowy z mego gołębnika" - tymi słowami żegnał I. Daszyński Janinę Benedekówną, która opuszczała biuro Oddziału Wywiadowczego przy ul. Krowoderskiej $7^{17}$.

We wrześniu 1914 r., po utworzeniu Polskiej Organizacji Narodowej (dalej: PON), Biurem Wywiadowczym z ramienia komisariatu głównego Organizacji zawiadywał Feliks Perl. Biuro Wywiadowcze PON zajmowało się kancelarią, a działania wywiadowcze pozostawały w rękach Oddziału Wywiadowczego. Aleksandra Szczerbińska miała realny wpływ na kierowanie Biura Wywiadowczego, choć pozostawała pod komendą Rajmunda Jaworowskiego, który dowództwo nad Oddziałem Kuriersko-Wywiadowczym przejął z rąk Walerego Sławka. Zastępcą „Świętopełka” był Adam Skwarczyński, jego zaś zastępował ppor. Stanisław Hempe ${ }^{18}$. Przez trzy wrześniowe dni (od 11 do 14) 1914 r. Oddział stacjonował w Olkuszu pod komendą A. Skwarczyńskiego. Stąd wywiadowczynie zostały wysłane do Warszawy, Łodzi i Radomia ${ }^{19}$. Następnie Oddział kwaterował w Krakowie (15 września - 5 października 1914 r.), następnie w Dąbrowie Górniczej, Sosnowcu, a z początkiem listopada w Zagórzu koło Sosnowca. Kwatera została urządzona w dworku fabrykanta Józefa Wrzoska ${ }^{20}$. Już z Olkusza A. Skwarczyński rozesłał kurierki do Warszawy, Łodzi i Radomia, oddział miał bowiem nadal pełnić zakordonowe misje wywiadowcze ${ }^{21}$.

Po wycofaniu się z Kielc Oddziałów I Brygady, 30 października 1914 r. Aleksandra Szczerbińska „Ola” przejęła z rąk Kazimierza Sawickiego komendę nad oddziałem kobiecym. Oddział Kuriersko-Wywiadowczy został zreorganizowany

16 J. Du frat, op. cit., s. 119-120.

17 J. B e ne de kó w n a, Za Bug, [w:] Wierna stużba. Wspomnienia uczestniczek walk o niepodległość 1910-1915, red. A. Piłsudska, M. Rychterówna, W. Pełczyńska, M. Dąbrowska, Warszawa 1927, s. 102.

18 R. Świętek, Lodowa ściana. Sekrety polityki Józefa Pitsudskiego 1904-1918, Kraków 1998, s. 727.

19 R. Starzyński, Cztery lata wojny w stużbie Komendanta. Przeżycia wojenne, Warszawa 1937, s. 77.

${ }^{20}$ R. Ś więt tek, op. cit., s. 754.

${ }^{21}$ J. G a u l, op. cit., s. 120. 
w momencie, gdy I Brygada utraciła prawo do samodzielnych ruchów. Działania wojenne utrudniało przedostawanie się osób cywilnych na teren Królestwa Polskiego, łączność z Warszawą została zerwana.

Zanim jednak A. Szczerbińska objęła komendę Oddziału Kuriersko-Wywiadowczego, była już mocno zaangażowana w działania wojenne. Była również bardzo dobrze przygotowana do przejęcia komendy. Znała podległe jej kurierki, organizowała dla nich przed wojną szkolenia w „Strzelcu”, z wieloma współpracowała już w czasie rewolucji $1905 \mathrm{r}$.

Dnia 1 sierpnia 1914 r. Aleksandra Szczerbińska wróciła z urlopu w górach do Lwowa. Powróciła też do swoich obowiązków biurowych, których musiała w momencie wybuchu wojny wziąć na siebie więcej, jej przełożony bowiem został zmobilizowany. Myślała jednak wyłącznie o tym, aby jak najszybciej zakończyć godziny pracy i udać się do komendy „Strzelca”. Wielu członków „Strzelca” zostało powołanych do wojska austriackiego, a w budynku kłębiły się tłumy ochotniczek, chętnych wziąc udział w wojnie. Nowe kandydatki na strzelczynie zostały zaproszone na spotkanie organizacyjne 2 sierpnia. Szczerbińska zachęcała je do wzięcia udziału w pracy kurierskiej i zgłoszenie się do wywiadu. Zapewniała o fachowym przygotowaniu, kursach i ważności tej służby. Większość kandydatek zgłosiła się jednak do służby sanitarnej22.

W dniu 2 sierpnia Szczerbińska otrzymała od Józefa Piłsudskiego list z prośbą, aby 4 sierpnia stawiła się w Krakowie. Wzięła urlop w biurze, a prace organizacyjne w „Strzelcu” przekazała R. Danyszównie, sama zaś wyruszyła nocnym pociągiem do Krakowa. Zabrała ze sobą kilka niezbędnych rzeczy: „wyprane” paszporty rosyjskie, pieczęcie gminne, małą ręczną drukarenkę z gumowym czcionkami oraz pensję za lipiec. W Krakowie spotkała się z Walerym Sławkiem, który zlecił jej dorobienie pieczęci do paszportów dla osób nielegalnie wyjeżdżających na teren Królestwa. Zamówiła potrzebne pieczęcie u grawera z Sukiennic, który miał je przygotować na 6 sierpnia. Z Piłsudskim widziała się tylko chwilę i spotkanie to miało charakter organizacyjny. Planował on bowiem wysłać Szczerbińską w towarzystwie Wandy Wasilewskiej, żony Leona Wasilewskiego ${ }^{23}$, z misją polityczną do Romana Dmowskiego, który wówczas przebywał w Warszawie. Celem tej misji miały być rozmowy dotyczące utworzenia Rządu Narodowego. Misja ta nie została zrealizowana ${ }^{24}$.

Dnia 6 sierpnia po południu Aleksandra Szczerbińska stawiła się na rozkaz Walerego Sławka na Oleandrach. Wyruszyła na teren Królestwa Polskiego w towarzystwie Janowej Klempińskiej, „Szarej” Janiny Benedekówny, Leona

${ }^{22}$ A. Piłsudska, Oddzial żeński „Strzelca” w sierpniu 1914 r., [w:] W czterdziestolecie wymarszu Legionów. Zbiór wspomnień, Londyn 1954, s. 7.

${ }^{23}$ Wojskowe Biuro Historyczne, Komitet Krzyża i Medalu Niepodległości. Akta personalne, sygn. KN 22.4.1938.

${ }^{24}$ A. Piłsud ska, Oddział żeński..., s. 8. 
Wasilewskiego i Gustawa Daniłłowskiego oraz kilku innych osób. Nad ranem 7 sierpnia dojechali bez przeszkód i rosyjskiej kontroli granicznej do Słomnik i spotkali się z oddziałami strzelców ${ }^{25}$.

Pierwsza wojna światowa rozpoczęła się dla Aleksandry Piłsudskiej 6 sierpnia 1914 r. Wymarsz Legionów z Krakowa i wkroczenie w granice Królestwa Polskiego oznaczał początek nowego etapu w jej życiu i działalności politycznej. Było to wydarzenie porównywane do powstań narodowych, którego rocznice świętowano już w czasie trwania pierwszej wojny. „Na posterunku”, periodyk wydawany pod auspicjami Ligi Kobiet, pisało z czcią o dokonaniach Piłsudskiego i Legionów. Aleksandra Szczerbińska była aktywną działaczką Ligi Kobiet ${ }^{26}$.

Wraz z wybuchem wojny Szczerbińska pracowała pod cywilną komendą Michała Sokolnickiego w Kielcach, a następnie objęła dowództwo wywiadowczego oddziału strzelczyń. Nie wzięła bezpośredniego udziału w walkach, koordynowała działania kurierek, które przenosiły i zdobywały informacje w różnych częściach kraju, przede wszystkim na terenie Królestwa Polskiego.

Aleksandra Szczerbińska od 1904 r. prowadziła nieustającą pracę rewolucyjną i niepodległościową. Od 1912 r. związana była z ruchem strzeleckim i wraz ze Strzelcami przekroczyła granice Królestwa Polskiego. W Kielcach pracowała z Gustawem Daniłowskim w biurze prasowym. Zajmowała się również „kwatermistrzostwem", dbała o zakwaterowanie dla przybywających do miasta żołnierzy i przedstawicieli władz ${ }^{27}$. Przebywała w mieście w czasie, kiedy było ono w rękach oddziałów Piłsudskiego i kiedy zostało ponownie odbite przez Rosjan. Obraz miasta i jego mieszkańców zatrwożonych wojną i absolutnie obojętnych wobec polskich żołnierzy utrwaliła we Wspomnieniach: „Miasto wyglądało jak umarłe, ulice puste, bramy domów zaryglowane. Tylko w domach widać było twarze mieszkańców Kielc, przypatrujące się wychodzącym oddziałom strzeleckim. Szłam pustymi ulicami, zastanawiając się co począć dalej. Nagle jakieś drzwi się otworzyły i poczciwie wyglądająca kobieta zaprosiła, abym weszła do pokoju. Ku mojej wielkiej radości zobaczyłam tam naszą strzelczynię ze Lwowa, która dowiedziawszy się, że nie mam gdzie nocować, podała mi adresy sympatyzujących z nami rodzin. Wkrótce znalazłam gościnę u miłych ludzi, którzy nie zawahali się przed ryzykiem przyjęcia osoby »nielegalnej«. Takich nie było, niestety, w Kielcach wielu"28.

Po opuszczeniu Kielc Aleksandra Szczerbińska znalazła się pod komendą Rajmunda Jaworowskiego. Mimo zmiany sytuacji na froncie i wycofaniu się armii austriackiej kurierki nie ustawały w pracy, oprócz nawiązania kontaktów z Królestwem, prowadziły wywiad aż po Mińsk i Odessę. Przewoziły przez front raporty przygotowane przez POW oraz wiadomości polityczne od organizacji

\footnotetext{
${ }^{25}$ Ibidem.

${ }^{26}$ „Na posterunku”, 6 VIII 1916, s. 1-16.

${ }^{27}$ R. Starzyński, op. cit., s. 67.

${ }^{28}$ A. Piłsudska, Wspomnienia, Łomianki 2004, s. 166.
} 
niepodległościowych. „Praca ich moralnie była bardzo uciążliwa, gdyż pracowały wśród obojętności społeczeństwa. Otrzymywały wyżywienie żołnierskie i ubranie, czasem gdy nie miały osobistych pieniędzy, otrzymywały pieniądze na drobne wydatki. Wyliczały się z pieniędzy branych na podróże. Pracowały ofiarnie i bezinteresownie"29 - pisała Szczerbińska. Obejmowała komendę nad oddziałem zorganizowanym i przygotowanym do prowadzenia dalszej pracy wywiadowczej.

Dowodzony przez nią Żeński Oddział Wywiadowczy jako część Oddziału Wywiadowczego podlegał najpierw I Pułkowi Piechoty Legionów, a następnie I Brygadzie. W oddziale tym służyło 46 kobiet. Były to członkinie Związku i Drużyn Strzeleckich, które miały kilkuletnie wykształcenie wojskowe. W Oddziale Kuriersko-Wywiadowczym służbę pełniły również kobiety należące do politycznych organizacji niepodległościowych. Kurierki rekrutowały się spośród polskiej inteligencji, przeważały wśród nich absolwentki i studentki uniwersytetów polskich oraz zagranicznych, nauczycielki, publicystki, ale również znalazły się trzy krawcowe. Były wśród nich kobiety bardzo młode, jak również w wieku emerytalnym, wiek kurierek wahał się od 20 do 65 lat ${ }^{30}$.

Rekrutacja do Żeńskiego Oddziału Kuriersko-Wywiadowczego prowadzona była od sierpnia do września 1914 r. W kobiecym oddziale po pierwszym naborze służyły m.in. Wanda Filipkowska, Wanda Wasilewska, Władysława Długoszowa, Irena Wasiutyńska, Janina Bendekówna. W pierwszej połowie września do oddziału, który stacjonował w Kielcach, dołączyły: Maria Nowicka, Jólia Sokólska, Maria Domańska, Bronisława Tynikówna, Stanisława Krasuska. Znalazły się one na terenie Królestwa Polskiego po ewakuacji Lwowa. W listopadzie 1914 r. w oddziale znalazło się dziewięć wywiadowczyń zwerbowanych przez Romana Starzyńskiego. Oddział stacjonował wówczas w Zagórzu ${ }^{31}$. Do oddziału przyjmowane były członkinie Związków Strzeleckich oraz kobiety znające język rosyjski. Organizowano dla nich kursy rekruckie i przygotowywano do pracy w terenie.

${ }^{29}$ Ibidem, s. 169.

${ }^{30}$ A. S z c zerbiń s ka, Oddział Wywiadowczy I Brygady, [w:] Wierna służba..., s. 82. Pełnego składu osobowego Oddziału Kuriersko-Wywiadowczego nie da się odtworzyć. Służyły w nim: Aleksandra Szczerbińska „Ola”, Stefania Minkiewicz „Westa”, Irena Sokolnicka, Wanda Martynowicz, Janina Sokołowska, Lang, Maria Popiel, Zofia Szybalska, Jadwiga Wróblewska, Maria Wiśniewska „Turzyma”, Irena Wasiutyńska, Maria Nowicka-Borowska, Stefania Flek „Fanka”, Janina Benedek „Szara”, Sława Długosz, Wanda Filipkowska „Makryna”, Waleria Golińska „Babcia”, Jadwiga Kadyi-Kwiatkowska, Konstancia Klempińska „Jadwiga”, Maria Korniłowicz-Strońska „Felicja”, Barbara Kossuth, Janina Kowalska, Stefania Kudelska „Hanna”, Dioniza Lipińska-Wyszyńska, Zofia Ostolska-Hanicka, Teresa Perlowa, Wanda Piekarska „Pociecha”, Hanna Pohoska-Rzepecka „Szczęsna”, Wanda Popławska, Maria Rychter „Marta”, Zofia Skrzyszowska, Julia Sokólska-Szczyrek, Helena Sujkowska, Julia Szartowska, Bronisława Tynik, Wanda Wyczałkowska, Zofia Zawiszanka „Wiśniowiecka”, Michalina Żychalówna; za: R. Ś w i ę t e k, op. cit., s. 727.

${ }^{31}$ J. Du frat, op. cit., s. 121. 
W początkowej fazie działalności Oddział nie miał stałej siedziby, do której kurierki mogłyby składać raporty. Komenda Oddziału podążała za Legionistami i początkowo raporty dostarczano do Miechowa, następnie do Jędrzejowa, Chęcin, Tumlina i Kielc, Częstochowy, Dąbrowy Górniczej, Sosnowca, by na początku listopada zakwaterować się w Zagórzu. Kwatera Oddziału mieściła się w dworku Józefa Wrzoska, przemysłowca i sympatyka ruchu niepodległościowego ${ }^{32}$.

Kurierki dostarczały informacji o ruchach wojsk rosyjskich, zapewniały łączność między Warszawą a Sztabem I Brygady, przewoziły rozkazy i polecenia Piłsudskiego. Nie raz musiały przekraczać linię frontu, co wiązało się z niebezpieczeństwem aresztowania. $\mathrm{Z}$ tego powodu $\mathrm{w}$ więzieniu rosyjskim znajdą się np. Stefania Kudelska, Wanda Wasilewska, Bronisława Bobrowska czy Waleria Golińska.

Działania Oddziału do sierpnia 1914 r. do września obejmowały wywiady taktyczne, które prowadzone były na lewym brzegu Wisły, gdzie walczył I pułk piechoty. Od grudnia 1914 r. do kwietnia 1915 r. wywiadowczynie pełniły przede wszystkim funkcje kurierskie ${ }^{33}$. Członkinie Oddziału Kuriersko-Wywiadowczego oprócz zdobywania informacji metodami wywiadowczymi zajmowały się organizacją sieci wywiadowczej. Na stacjach wywiadowczych kurierki otrzymywały pomoc w zdobyciu transportu, dokumenty, noclegi. Takie placówki powstały m.in. w Częstochowie, Kielcach, Radomiu, Płocku. Kurierki obowiązywał całkowity zakaz przekazywania informacji Austriakom. Zdobyte informacje trafiać miały wyłącznie do Komendy Oddziału.

Obowiązki komendantki oddziału kobiecego Aleksandra Szczerbińska wypełniała $\mathrm{z}$ troską o powierzone jej kurierki. Oddział znajdował się pod bezpośrednią komendą R. Jaworowskiego „Świętopełka”, który wraz z podległymi mu oficerami odbierał meldunki od przybywających z różnych stron kurierek. Bezpośrednio oddziałem kobiecym zajmowała się jednak Aleksandra Szczerbińska, była skarbniczką oddziału i zarazem komendantką. Odszyfrowywała raporty dostarczane przez kurierki i przekazywała je „Świętopełkowi”. Organizowała noclegi, wyżywienie dla przybywających kurierek. Zapewniała im warunki do wypoczynku i decydowała o ponownym wysłaniu ich w teren. Wydawała rozkazy dotyczące zaszeregowania i służby. Pośredniczyła w wydawaniu rozkazów kurierkom, które były całkowicie uzależnione od Jaworowskiego. Przygotowaniem do wypełnienia rozkazu zajmowała się jednak Szczerbińska, szczególnie wówczas, gdy rozkaz wymagał odwagi i związany był z narażaniem życia ${ }^{34}$.

Przygotowywała kurierki od strony technicznej, udzielała rad dotyczących obchodzenia się z ładunkami palnymi, szyła specjalne ubrania, w których ukryte

32 Ibidem, s. 122.

${ }^{33}$ W. Tokarz, Wstęp, [w:] Legiony na polu walki. Działania pierwszego putku legionów na lewym brzegu Wisty w sierpniu i wrześniu 1914 roku. Relacje uczestników, Warszawa 1916, s. 5-32.

${ }^{34}$ Z. Zawiszanka, op. cit., s. 194-196. 
były nielegalne materiały. Miała w tej materii doświadczenie zdobyte w czasie rewolucji 1905 r. Był to dla Aleksandry Szczerbińskiej również czas, kiedy zawiązywały się przyjaźnie, które przetrwały wojnę. Jedną z najwierniejszych przyjaciółek A. Szczerbińskiej była Teresa Perlowa, która w 1918 r. pomagała jej w opiece nad pierworodną córką Wandą. W oddziale Kuriersko-Wywiadowczym T. Perlowa zajmowała się zakwaterowaniem oraz wyżywieniem ${ }^{35}$.

We wspomnieniach towarzyszek broni „Ola” jawiła się jako osoba niezwykle opanowana, dystyngowana, spokojna i małomówna ${ }^{36}$, a także jako odważna i zdeterminowana, która doskonale nadawała się na komendantkę kurierek. „Komendę nad tym oddziałem sprawowała ob. Ola, która wraz ob. Westą (Stefania Minkiewiczowa), należały niegdyś do Organizacji Bojowej PPS, bywały więc pod wozem i na wozie, nigdy nie traciły ducha i teraz spokojnie patrzyły w przyszłość jak wszyscy, którzy kiedykolwiek mieli do czynienia z Komendantem i wierzyli Mu bezgranicznie" ${ }^{37}$. Odwaga towarzyszki Oli podkreślana była w wielu relacjach z pierwszej wojny światowej, zawsze gotowa była najtrudniejsze zadania powierzyć sobie i z narażeniem życia je wypełnićs ${ }^{38}$.

Była też w najbliższych relacjach z Komendantem Piłsudskim, co powodowało zazdrość kurierek. Podczas wizyt Komendanta uczestniczyła we wszystkich naradach sztabowych ${ }^{39}$. Piłsudski instruował A. Szczerbińską: „Pamiętajcie, że praca wasza polega na zbieraniu informacji niejako w stanie surowym. Sztab je zanalizuje i wybierze, co trzeba. Nie martwcie się, że czasem wyniki waszej pracy będą wydawały się wam błahe. Najmniejszy nawet szczegół na oko bez wartości, może się przydać, może odegrać wielką rolę w przygotowaniu planu"40.

Była podkomendną R. Jaworowskiego, a ponadto była osobą bardzo dobrze zorientowaną w planach i intencjach działania politycznego Józefa Piłsudskiego. Musiało to prowadzić do konfliktów i różnicy zdań między komendantem oddziału wywiadowczego a komendantką kurierek. „Stosunki służbowe z oficerami układały się trochę opornie wskutek osobliwego rozkładu pracy w oddziale; myśmy tu były jedyne, które miały kontakt z wrogiem, tj. pełniłyśmy służbę przed frontem. Mimo to niechętnie przyznawano nam przynależność wojskową. Traktowano nas bowiem jako podkomendne, pozbawione przywilejów służbowych, a obdarzane przywilejami towarzyskimi poza służbą. Na tym tle powstawały niewielkie konflikty" ${ }^{41}$ - tak charakteryzowała atmosferę panującą w sztabie w Za-

${ }^{35}$ R. F1eszarow a, Oddział Żeński Lwowskiego Związu Strzeleckiego w czasie mobilizacji, [w:] Wierna stużba..., s. 47; R. Ś wi ę t e k, op. cit., s. 755.

${ }^{36}$ Z. Zawiszanka, op. cit., s. 191.

${ }^{37}$ R. Starzyński, op. cit., s. 76.

${ }^{38}$ R. Halny, Aleksandra Piłsudska komendantka wywiadu kobiecego, Warszawa [b.r.], s. 8-9.

${ }^{39}$ M. Rychterówna, Listopad w Zagórzu, [w:] Wierna stużba..., s. 95-101; Aldona, Wywiad w Karpackiej Brygadzie, [w:] ibidem, s. 125-126.

${ }^{40}$ A. Piłsudska, Wspomnienia..., s. 140.

${ }^{41}$ M. Rychterówna, op. cit., s. 99. 
górzu Maria Rychterówna. Wywiadowczynie spotykały się z niezrozumieniem swojej postawy, nie doceniano ich służby i niekiedy traktowano jak kobiety do towarzystwa.

Kurierki uważały, że są żołnierzami, że rozkazy, które wypełniały, i działania, które prowadziły, skazywały je na żołnierski los. Porównywały się do emisariuszek z powstania styczniowego: „,...] burze, błyskawice, słońca. Ale co tam! Byle dalej - byle naprzód!"’42. Zdawały sobie z tego sprawę z tego, że podejmowane przez nie misje były niebezpieczne. Prowadziły je z narażeniem życia czy obawą przed aresztowaniem. „Jechaliśmy teraz na losy całkiem niewiadome, na poszukiwanie naszego pułku, gdzieś w nieuchwytnej przestrzeni zmiennego teatru wojny. [...] Był w tym urok ruchu i ryzyka, żołnierska niepewność jutra, która czyni każdą godzinę pełnią radosną... żywioł wojenny stworzony dla natur takich, jak moja. Poczułam się teraz zdolna do wszelkich wysiłków, nieustraszona. Bo już po południu tegoż dnia przekonaliśmy się, że owe przejście Wisły nie było wcale śmiałym wymysłem naszych informatorów"43 - zapisała po jednej z misji wywiadowczych Z. Zawiszanka.

Kurierki nie miały stopni wojskowych, nie były żołnierkami, nie podlegały regulaminom wojskowym. Prowadziło to niekiedy do nieporozumień i konfliktów, chciały być bowiem traktowane jako integralna część Legionów.

Konflikty te próbował łagodzić sam Józef Piłsudski. W liście do Aleksandry Szczerbińskiej z końca roku 1914 odnosił się do spięcia między Rajmundem Jaworowskim a Aleksandrą Szczerbińską. Jaworowski, oficer Legionów, przyjaciel Piłsudskiego, był komendantem oddziału wywiadowczego i znajdował się wówczas w konflikcie z Departamentem Wojskowym Naczelnego Komitetu Narodowego. Piłsudski, powołując się na przyjaźn z Jaworowskim, prosił Aleksandrę o zaniechanie sporu ${ }^{44}$.

Współpraca z Rajmundem Jaworowskim była trudna ze względu na jego porywczy charakter, jak również wysokie wymagania, jakie stawiał swoim podwładnym. Zawiszanka wspominała jedno ze spotkań z R. Jaworowskim: „Mój przełożony objawił niezadowolenie, że dotąd wcale nie spotkałam się z Moskalami. Jedźcie tak długo, aż ich złapiecie! - powtarzał stanowczo - wywiadowczyni powinna mieć stały kontakt z nieprzyjacielem!"’45.

Dnia 25 marca 1915 r. austriackie władze wojskowe wydały rozkaz o likwidacji Oddziału Wywiadowczego. Tym samym kobiety utraciły ,jedyny prawie dostępny im rodzaj służby frontowej".

W kwietniu 1915 r. rozkazem Komendanta rozwiązany został Oddział Wywiadowczy I Brygady. Kurierki rozproszyły się i przystąpiły do innych działań

${ }^{42}$ Instytut Józefa Piłsudskiego w Londynie [dalej: IJPL], Wanda Pełczyńska, sygn. 202/20, karty bez paginacji.

${ }^{43} \mathrm{Z}$. Z a w is za nk a, W pogoni za swoim pułkiem, Legiony, IJPL, sygn. 22/9, k. 4.

44 J. Piłsudski do A. Szczerbińskiej, Jabłonków 24 XII 1914, [w:] Z. W ó j c i k, Z listów Józefa Pitsudskiego do Aleksandry Szczerbińskiej, „Tygodnik Powszechny” 1988, nr 46, s. 4.

${ }^{45}$ Z. Zawiszanka, op. cit., s. 34-35. 
niepodległościowych. Aleksandra Szczerbińska, Maria Rychterówna i Stefania Minkiewiczowa wyjechały do Dąbrowy Górniczej i rozpoczęły współpracę z lokalnymi strukturami PPS i Ligi Kobiet ${ }^{46}$.

Praca kurierek spotkała się z pochwałami i uznaniem Józefa Piłsudskiego, który początkowo zachowywał dystans wobec udziału kobiet w wojnie. Później doceniał ofiarność, poświęcenie i wytrwałość w działaniach, którymi wykazały się bojowniczki z Kobiecego Oddziału Kurierskiego: „Strasznym jest dla każdego żołnierza moment pierwszego boju. Wy nie znacie tego uczucia, ale chłopcy idą ramię przy ramieniu w otwarty bój, są między swymi. Wy... idziecie samotne, wśród obcych wam ludzi i narażacie się na cięższą niż żołnierska śmierć... I nigdy nie zaznacie radości, jaką daje masowe zwycięstwo!"'47.

W moich pierwszych bojach wracał do tego wątku, pisząc: „Wielka jest zaiste zasługa Beliny [Władysława Prażmowskiego], i mego biura wywiadowczego, złożonego prawie wyłącznie z kobiet, że mogłem wówczas posiadać dane o nieprzyjacielu. Belina dokonywał po prostu cudów. [...] Jeszcze bardziej ofiarnie pełniły służbę kobiety. Na furmankach tłukły się one samotnie, po wszystkich drogach zataczając kręgi znacznie obszerniejsze niż jazda, bo sięgające do Warszawy, Piotrkowa i Dęblina. [...] Sam więc byłem spokojny"48.

W patetycznym tonie podsumował działania kurierek Roman Halny (Adam Próchnik): „Na szlaku tajnych wywiadów nie miały towarzyszy. Samotnie przedzierały się przez linię frontu, samotnie brnęly przez pola i lasy pełne poświstów kul i pękających szrapneli. O głodzie i chłodzie niepomne zmęczenia, przemierzały dziesiątki kilometrów, na wozie czy pieszo, w dzień czy w nocy, byle dotrzeć do celu"49.

Polski oddział wywiadowczy był wysoko oceniany przez niemieckie dowództwo, podziwiano pracę dla idei, która prowadzona była z niezwykłym poświęceniem. Zawiszanka zapisała w swoich wspomnieniach opinie por. Wenigera ze sztabu dowództwa niemieckiej armii: „Żadne zadanie nie jest dla was zbyt trudne, bo działacie dla idei... Ach, gdybyśmy mieli takie „narodowe urządzenie” (National-Einrichtung) inaczej by szła cała ta wojna. Ale nasze kobiety nie chciały słyszeć o tym [...] to zupełnie inny gatunek! Wasza służba jest wyjątkiem, czymś niesłychanym w dziejach wojen - i może naprawdę początkiem jedynie racjonalnego postawienia kwestii wywiadu" 50 .

W 1917 r. Komendant Piłsudski odznaczył 20 kurierek odznaką I Brygady za „Wierną Służbę”. Za służbę w Oddziale Wywiadowczym kurierki zostały również podane do odznaczenia Krzyżem Virtuti Militari. Komenda Oddziału Wywiadowczego wskazała siedem nazwisk do tego najwyższego wojennego orderu,

${ }^{46}$ M. Rychterówna, op. cit., s. 193.

${ }^{47}$ Słowa wypowiedziane przez Józefa Piłsudskiego w czasie odprawy Oddziału Wywiadowczego I Brygady w Zagórzu w 1915 r., cyt. za: Wierna stużba..., s. 2.

48 J. Piłsuds ki, Moje pierwsze boje, Łódź 1988, s. 29.

${ }^{49}$ R. Halny, op. cit., s. 3.

${ }^{50}$ Z. Zawiszanka, op. cit., s. 216; J. Gau 1, op. cit., s. 111. 
były to: Władysława Długoszowa, Wanda Filipkowska, Waleria Golińska, Felicja Klempińska, Maria Korniłowiczówna, Maria Rychterówna, Maria Turzyma. Krzyżem Walecznych zostało odznaczonych 17 kurierek $^{51}$.

Na II zjeździe legionistów w 1923 r. we Lwowie Józef Piłsudski podsumował prace kurierek: „Pierwsze poszły za nami kobiety. Kobiety czuły silnie piękno życia, odczuły te przekorę legunową, która szła wbrew całemu światu, która szła przebojem przeciw własnemu społeczeństwu żądając od niego, jeżeli nie uznania, to szacunku dla polskiego żołnierza. W ślad za nami, trop w trop za naszym żołnierzem idą kobiety, oczarowane pięknem duszy, pięknem wartości moralnej, którąśmy z siebie wydobyli” ${ }^{52}$.

Postawa, odwaga, determinacja wywiadowczyń z Żeńskiego Oddziału Kuriersko-Wywiadowczego wielokrotnie znajdowała uznanie w opiniach Józefa Piłsudskiego. Ponadto Aleksandra Szczerbińska podkreślała nie tylko zasługi kurierek, lecz mówiła także o niezwykle trudnej sytuacji, w której znajdowały się kobiety służące w wojsku. Nie zawsze szanowane, często narażone na kontakty z żołnierzami wrogiej armii, które stanowić mogły zagrożenie dla ich zdrowia i życia. Służba kurierek nie została w pełni doceniona. Wydanie wspomnień kobiet, które uczestniczyły w walkach o niepodległość, miało zagwarantować im stałą obecność na kartach historii oraz oddać hołd ich służbie żołnierskiej i patriotycznej postawie. Z inicjatywy Aleksandry Piłsudskiej zostały zebrane i wydane w dwóch tomach wspomnienia uczestniczek pierwszej wojny światowej. Publikacja ta była świadectwem feministycznej postawy Piłsudskiej, jej deklaracją ideową i manifestem. Wierna stużba. Wspomnienia uczestniczek walk o niepodległość 1910-1915 (Warszawa 1927); Stużba ojczyźnie. Wspomnienia uczestniczek walk o niepodległość 1915-1918 (Warszawa 1929) - książki te miały na celu zebranie informacji dotyczących udziału kobiet zaangażowanych w działalność patriotyczną i bojową przed wybuchem pierwszej wojny światowej oraz w czasie jej trwania, kobiet, które zmobilizowane były pod komendą Józefa Piłsudskiego. Wydawnictwo miało charakter pionierski, niemający wzorów w literaturze polskiej i obcej. Redaktorki tomu pisały we wstępie tonem pełnym patosu: „Nie jest to historia. Są to osobiste wspomnienia uczestniczek ważnych wypadków dziejowych, ujęte wszakże w ramy ciągłości historycznej. Niechaj ta mała karta w wielkiej księdze walki o życie Narodu będzie świadectwem konkretnego czy$\mathrm{nu}$, podejmowanego $\mathrm{z}$ radosną wiarą $\mathrm{w}$ sprawę i Wodza" ${ }^{53}$. Uczestniczki tych wydarzeń oraz ich wspomnienia zostały przez historyków zapomniane. Narracje kobiet sporadycznie są dziś wykorzystywane w pracach poświęconych pierwszej wojnie światowej. W biografii Aleksandry Piłsudskiej wydarzenia związane z okresem walk o niepodległość stanowią najciekawszy i najważniejszy fragment

${ }^{51}$ A. Szczerbiń ska, op. cit., s. 81-83. Order Virtuti Militari otrzymały: Władysława Długoszowa, Wanda Filipkowska, Waleria Golińska, Maria Rychterówna.

${ }^{52}$ J. P iłs u d s ki, Pisma zbiorowe, t. VI, Warszawa 1937, s. 69-70.

53 Wierna stużba..., s. VII. 
jej życia. Do historii przeszła jednak nie jako komendantka Żeńskiego Oddziału Kuriersko-Wywiadowczego, ale jako Pani Marszałkowa.

\section{Bibliografia}

\section{ŹRÓDEA ARCHIWALNE}

Instytut Józefa Piłsudskiego w Londynie [dalej: IJPL]

Wanda Pełczyńska, sygn. 202/20.

Z. Zawiszanka, W pogoni za swoim pułkiem, Legiony, sygn. 22/9.

\section{ŹRÓDEA DRUKOWANE}

Aldona, Wywiad w Karpackiej Brygadzie, [w:] Wierna służba. Wspomnienia uczestniczek walk o niepodległość 1910-1915, red. A. Piłsudska, M. Rychterówna, W. Pełczyńska, M. Dąbrowska, Warszawa 1927, s. 125-131.

Bagiński H., Utworzenie organizacji skautowej w Sokole, [w:] Zarzewie 1909-1920. Wspomnienia i materiaty, red. A. Garlicka, Warszawa 1973, s. 13-25.

Benedekówna J., Za Bug, [w:] Wierna stużba. Wspomnienia uczestniczek walk o niepodległość 1910-1915, red. A. Piłsudska, M. Rychterówna, W. Pełczyńska, M. Dąbrowska, Warszawa 1927, s. $102-104$.

Fleszarowa R., Oddział Żeński Lwowskiego Zwiazku Strzeleckiego w czasie mobilizacji, [w:] Wierna stużba. Wspomnienia uczestniczek walk o niepodległość 1910-1915, red. A. Piłsudska, M. Rychterówna, W. Pełczyńska, M. Dąbrowska, Warszawa 1927, s. 46-50.

Piłsudska A., Oddział żeński „Strzelca” w sierpniu 1914 r., [w:] W czterdziestolecie wymarszu Legionów. Zbiór wspomnień, Londyn 1954, s. 6-12.

Piłsudska A., Przedmowa, [w:] Z. Zawiszanka, Przez fronty. Pamiętnik wywiadowczyni 1 pułku piechoty Legionów z 1914 roku. Na podstawie notatek spisanych w lutym-marcu 1915 r., Warszawa 1928, s. 4-6.

Piłsudska A., Wspomnienia, Łomianki 2004.

Piłsudski J., Moje pierwsze boje, Łódź 1988.

Piłsudski J., Pisma zbiorowe, t. VI, Warszawa 1937.

Rychterówna M., Listopad w Zagórzu, [w:] Wierna stużba. Wspomnienia uczestniczek walk o niepodległość 1910-1915, red. A. Piłsudska, M. Rychterówna, W. Pełczyńska, M. Dąbrowska, Warszawa 1927, s. 95-101.

Rychterówna M., Z dala od frontu, [w:] Wierna stużba. Wspomnienia uczestniczek walk o niepodległość 1910-1915, red. A. Piłsudska, M. Rychterówna, W. Pełczyńska, M. Dąbrowska, Warszawa 1927, s. 193-197.

Starzyński R., Cztery lata wojny w stużbie Komendanta. Przeżycia wojenne, Warszawa 1937.

Szczerbińska A., Oddział Wywiadowczy I Brygady, [w:] Wierna służba. Wspomnienia uczestniczek walk o niepodległość 1910-1915, red. A. Piłsudska, M. Rychterówna, W. Pełczyńska, M. Dąbrowska, Warszawa 1927, s. 81-84.

Zawiszanka Z., Poprzez fronty. Pamiętnik wywiadowczyni 1 pułku piechoty Legionów z 1914 roku. Na podstawie notatek spisanych w lutym-marcu 1915 r., Warszawa 1928. 


\section{Opracowania}

Chwalba A., Samobójstwo Europy. Wielka wojna 1914-1918, Kraków 2014.

Cieślikowa A., Udziat Polek w pierwszej wojnie światowej, [w:] Kobiety w konspiracji pierwszej $i$ drugiej wojny światowej. Materiały z sesji popularnonaukowej w Krakowie w dniu 18 maja 2005 roku, red. K. Minczykowska, J. Sziling, Toruń 2006, s. 15-20.

Dufrat J., Kobiety w kręgu lewicy niepodlegtościowej. Od Ligi Kobiet Pogotowia Wojennego do Ochotniczej Legii Kobiet (1908-1918/1919), Torun 2001.

Gaul J., Na tajnym froncie. Działalność wywiadowczo informacyjna obozu niepodległościowego w latach 1914-1918, Warszawa 2001.

Grzywacz M., Okupnik M., Wstęp, [w:] Kobiety i/a doświadczenie wojny 1914-1945 i później, red. M. Grzywacz, M. Okupnik, Poznań 2015, s. 8-13.

Halny R., Aleksandra Pitsudska komendantka wywiadu kobiecego, Warszawa [b.r.].

Marcinkiewicz-Gołaś A., Ochotnicza Legia Kobiet (1918-1922), Warszawa 2006.

Piłsudska A., Udział kobiet w walkach o niepodległość, „Niepodległość” [Londyn] 1955, t. V, s. $169-188$.

Strug A., Wiekopomny dzień 6 sierpnia 1914, Warszawa 1926.

Świętek R., Lodowa ściana. Sekrety polityki Józefa Pitsudskiego 1904-1918, Kraków 1998.

Wójcik Z., Z listów Józefa Pitsudskiego do Aleksandry Szczerbińskiej, „Tygodnik Powszechny” 1988, nr 46, s. 4-5.

Wrzosek M., Polski czyn zbrojny podczas pierwszej wojny światowej, Warszawa 1990.

Tokarz W., Wstęp, [w:] Legiony na polu walki. Działania pierwszego pułku legionów na lewym brzegu Wisty w sierpniu i wrześniu 1914 roku. Relacje uczestników, Warszawa 1916, s. 5-14.

\section{Marta SiKorsKa-Kowalska}

\section{Commandant of the Women's Courier and Intelligence Unit of the $1^{\text {st }}$ Birigade of the Polish Legions. Aleksandra Szczerbińska and her siters in arms}

$\mathrm{T}$ he paper presents the origins and activities of Women's Courier and Intelligence Unit commanded by Aleksandra Szczerbińska. She became a Head of this Unit after it was retreated from Kielce together with troops of the $1^{\text {st }}$ Brigade on $30^{\text {th }}$ October 1914 . This Unit was earlier commanded by Kazimierz Sawicki and was firstly a part of Intelligence Unit in the $1^{\text {st }}$ Infantry Regiment, then in the $1^{\text {st }}$ Brigade. The Unit consisted of 46 women, previous members of Shooting Troops, having few years of military experience. Some of them were also active members of independent political organizations. Bravery and skills of the members of Women's Courier and Intelligence Unit were strongly appreciated by Józef Piłsudski.

Keywords: women's history, history of the $1^{\text {st }}$ World War, biography. 